\title{
Earthquake potential source identification using magnetotelluric data of Kendeng thrust Surabaya area
}

\author{
Amien Widodo ${ }^{1}$, Firman Syaifuddin ${ }^{1 *}$, Wien Lestari ${ }^{1}$ and Dwa Desa Warnana $^{1}$ \\ ${ }^{1}$ Institut Teknologi Sepuluh Nopember Surabaya, J1. Raya ITS, Keputih, Kec. Sukolilo, Kota SBY, JawaTimur 60111
}

\begin{abstract}
The existence of the kendeng fault passing Surabaya is still the subject of study by the researchers after being declared active by the National Earthquake Centre. The Surabaya was passed by two segments of the Kendeng fault, the Surabaya segment and the Waru segment, the two segments had an earthquake potential of 6.5 M. In the context of disaster mitigation and earthquake analysis, more detailed information is needed relating to the geometry and position of the earthquake source with certainty, so that the identification of earthquake sources is needed in more detail. The magnetotelluric method is one of the geophysical methods that is able to properly identify anomalous objects in tens of kilometers depth. Kendeng fault as a potential earthquake source, one of its segments across Surabaya can be identified using the magnetotelluric method. Megnetolelluric measurements were carried out as many as 15 points in the Surabaya region in order to identify the geometry of the kendeng fault. From the 3D resistivity model, the inversion of magnetotelluric data can be identified well with the Kendeng fault that crosses the city of Surabaya, both the Waru segment and the Surabaya segment at a depth of less than $8 \mathrm{~km}$
\end{abstract}

\section{Introduction}

Indonesia occupies a very active tectonic zone because the three large plates of the world and nine other small plates meet each other in the territory of Indonesia and forming complex plate meeting paths (Bird, 2003) (Fig 1). The existence of an interaction between these plates places the territory of Indonesia as a very territory prone to earthquakes (Milson et al., 1992). Material and human soul victims due to the earthquake were caused more by ignorance of a fault in an area, so that there was no anticipation of facing the movement of the fault. Therefore active fault mapping is needed for the development of spatial planning in Indonesia because from now on the construction of buildings must look at the disaster aspects of one of the earthquakes.

Geodetic studies using the Global Positioning System (GPS) have been carried out on measurements of surface deformation on Java (Koulali et al., 2016) (Fig 2). Koulali, et al. (2016) identified an extension or active extension of Flores back-arc thrust to the west along $300 \mathrm{~km}$ on land to East Java along Pateng Kendeng. The results of this study indicate the threat of a new large earthquake for East Java and the threat of a tsunami to Bali, Lombok, Nusa Tenggara, and other beaches along the Flores Sea. The discovery of active faults is the basis for the revision of the 2017 national earthquake map by the National Earthquake Center (PusGeN) team formed by the Ministry of Public Works and Public Housing. Two active faults based on the revised 2017 national earthquake map that crosses the city of Surabaya and its surroundings are Sesar Kendeng and Sesar Waru (Pusgen and PUPR, 2017).

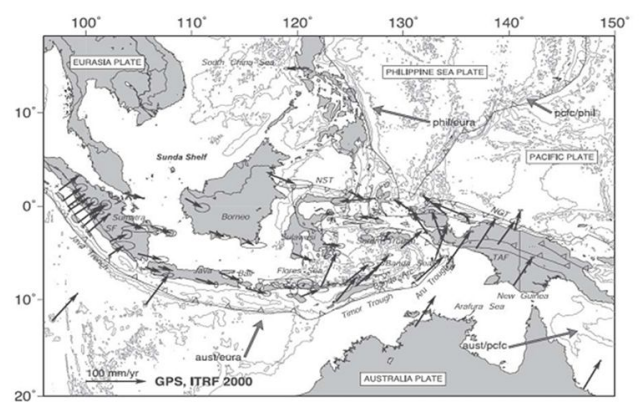

Fig. 1. Tectonic maps of the Indonesian archipelago and its surroundings (Bock et al., 2003).

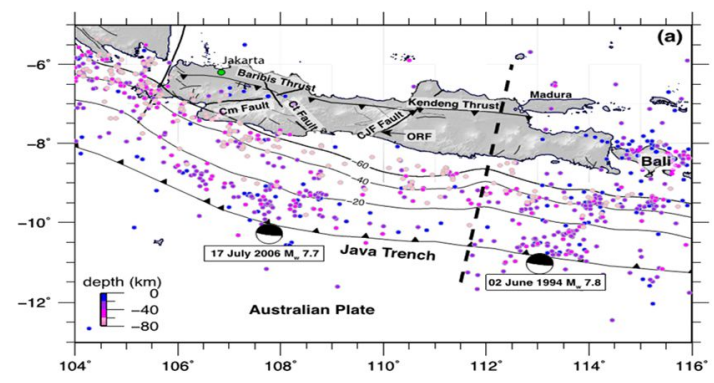

Fig. 2. Regional Tectonic Maps of the Main Faults of Java Island (Koulali et al., 2016).

Information about faults near the surface is the basis of studies of deformation studies in deeper areas. The Surabaya and surrounding areas are crossed by the active Tongue and Broken Kedung Waru faults associated with the Tongue Anticline, the Gaylin Anticline and the Kedung Waru Anticline (PPPG Geological Sheet, 1992). The Surabaya area is mostly alluvium deposits, the remainder in the form of low hills 
of weathering from tertiary rocks so that it is susceptible to earthquake amplification and areas with high population density are the main reasons for the importance of mitigation against earthquake threats. However, data or research on the dimensions and depth of faults in the Surabaya area and its surroundings is still incomplete. Some active fault studies using Seismic Method and GPS have not been able to explain in detail the relationship between earthquake processes that occur with the distribution of physical parameters such as resistivity, porosity and permeability, which are important parameters with the earthquake process. The magnetotelluric method is a passive electromagnetic method to determine the conductivity of the subsurface of the earth from a depth of tens of meters to thousands of meters (Simpson and Bahr, 2005). These structural zones are associated with high conductivity values due to the fluid content that fills the geological structure (Bedrosian et al. 2004; Unsworth et al. 2000). This research is expected to produce comprehensive and more detailed information about the deformation process of Surabaya and its surrounding subsurface structures from the North to the South through mapping the active geological structure zones seen from the subsurface resistivity distribution and its relation to other geophysical methods.

The objectives of this study are: (1) to know the distribution of subsurface resistivity in the Surabaya and surrounding areas from North to South using the Magnetoteluric Method, and (2) to detect the patterns and dimensions of active geological structures that develop in the Surabaya region and beyond through data on the resistivity of the Magnetoteluric Method.

The benefits of this research are that information about subsurface and active geological structures can be a preliminary study for disaster studies, especially earthquakes in the Surabaya and surrounding areas. Continuous studies of active fault movement in the next research area can be the primary disaster mitigation data of local governments by making earthquake risk maps in the study area.

\section{Regional Geology of Research Area}

In general, there are three directions of a general pattern of structures, namely the Northeast-Southwest (NE-SW) pattern called the Meratus pattern, North-South $(\mathrm{N}-\mathrm{S})$ or Sunda and East-West (E-W) patterns. Changes in the lime-age subduction path that traverses Northeast Southwest (NE-SW) to be relatively East-West (E-W). Since the Oligocene until now, it has produced a very complicated Tertiary geological order on the island of Java as, seen in Fig 2. The stratigraphic section given by Kusumadinata, 1975 in Pulunggono, 1994 shows that there are two groups of basins, namely the western part of the North Java basin, which has a longitudinal geometric shape relatively north-south with a basin boundary in the form of faults with south and east-west directions. Whereas the basins in the eastern part of the North Java basin group generally have an east-west elongated geometry with a more east-west structure that is more dominant.

At the end of the Cretasius subduction zone was formed, which formed in the Karangsambung area until the Meratus Mountains in Kalimantan. This zone forms the skeletal structure of the geological structure that has a northeast-southwest direction. Then the tertiary pattern shifts so that the subduction zone is in the south of Java. In this pattern, the structure formed is directed east-west. The collision between the Asian plate and the Australian plate produces the main force of north-south compression. This style forms the oblique wrench fault pattern with the northwest-southeast direction, which is more or less in line with the Cretacius final mountain pattern. In the Pliocene-Pleistocene period, the direction of the main stress is still the same, namely north-south. The tectonic activity of this period produces an upward and fold-up structure pattern that can be identified in the Kendeng Zone. The existence of a large north-south fault slightly curved facing the Lumajang depression was the cause of Lumajang's indentation and depression. This big fault can explain the straightness of the SemeruBromo-Penanjakan volcano.

The Surabaya and surrounding areas are traversed by several geological structures, as shown in Fig 3, among them the Tongue Anticline, the Anticline Gayungan and the Kedung Waru Anticline and the active faults of the Kedung Waru Tongue and Fault (PPPG Geology Sheet, 1992), which are associated with the anticline causing the Surabaya area and the surrounding area has the potential for an earthquake.

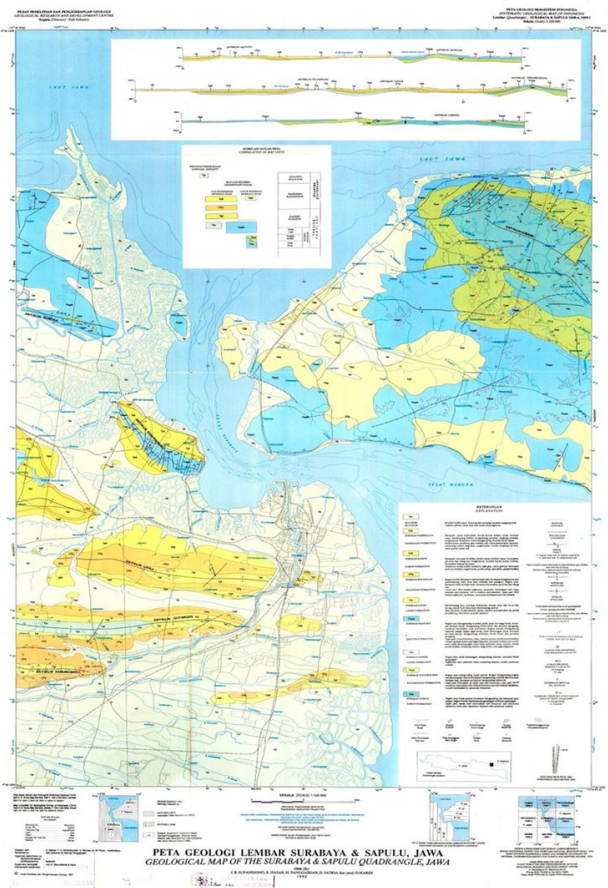

Fig. 3. Surabaya Sapuluh Geological Sheet (PPPG, 1992).

\subsection{Physiography of Research Area}

The physiographic area of research is located in the Rembang Anticline / Rembang Zone (Rembang Zone) where its forming rocks consist of shallow marine 
deposits, clastic sediments, and carbonate rocks. In this zone, there is also a fault called Rembang High and many folds that are east-west directed and the Kendeng Anticline / Kendeng Zone (Kendeng Zone) where the forming rocks consist of volcanogenic sequences and pelagic sediments (Fig 4).

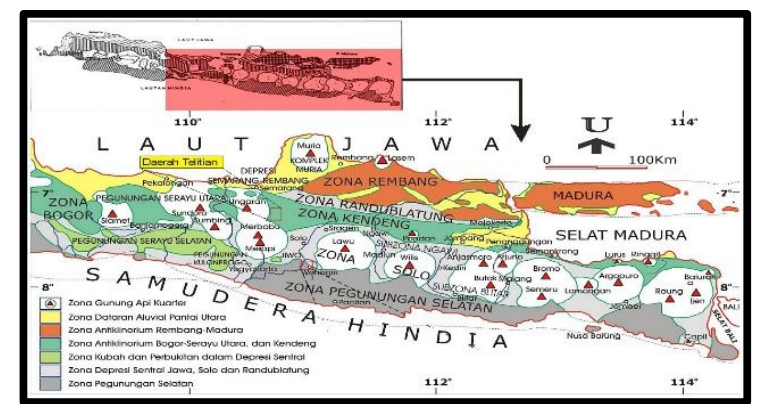

Fig. 4. Physiographic map of East Java (Van Bemmelen, 1949).

\section{Magnetoteluric Method}

The Magnetotelluric method is a passive electromagnetic (EM) method that measures the fluctuations of the electric field (E) and the natural magnetic field (B) in the orthogonal direction with the aim of determining the subsurface conductivity of the earth from tens of meters to thousands of meters (Simpson and Bahr , 2005). The range of frequency values of the natural electromagnetic fields recorded by the device is $320-0.001 \mathrm{~Hz}$. Natural electromagnetic fields (primary electromagnetic fields) as a source of magnetotelluric methods get to Earth by having variations with time. The electromagnetic field induces ore bodies beneath the surface of the Earth to create eddy current, which gives rise to secondary electromagnetic fields. The receiver (RX) located on the surface captures the total electromagnetic field as a sum of primary electromagnetic fields and secondary electromagnetic fields (David, 2011). The process is illustrated in Fig 5.

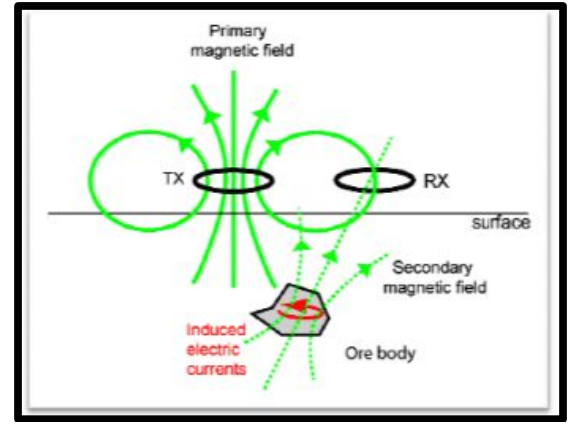

Fig. 5. Basic Principles of the Magnetotelluric Method (Unsworth, 2010)

\subsection{Magnetotelluric Data Acquisition}

The measurement of Magnetoteluric Method measurement data was carried out over the city of Surabaya as many as 15 sounding points (Fig 6 \& Table 1). The measurement path crosses the active structures found on the geological map. The measured data is a magnetic field in the direction of $\mathrm{x}, \mathrm{y}, \mathrm{z}$ or $\mathrm{Bx}, \mathrm{By}$, and $\mathrm{Bz}$, while the electric field is measured in the direction of $\mathrm{x}$ and $\mathrm{y}$ or Ex and Ey. By default, the directions $\mathrm{x}, \mathrm{y}$, and $\mathrm{z}$ are east-west, north-south, and up.

MT acquisition equipment consists of 3 parts, namely main unit, coil and porous pot. The electric field is obtained by measuring the potential difference at two certain distance points, then dividing that value by its distance or according to the equation below:

$$
\mathrm{E}=\mathrm{U} / \mathrm{d}
$$

Where $E$ is an electric field, $U$ is a potential difference, $\mathrm{d}$ is the distance between electrodes. The arrangement of the main unit, coil and porous pot can be seen in Fig 7 below.

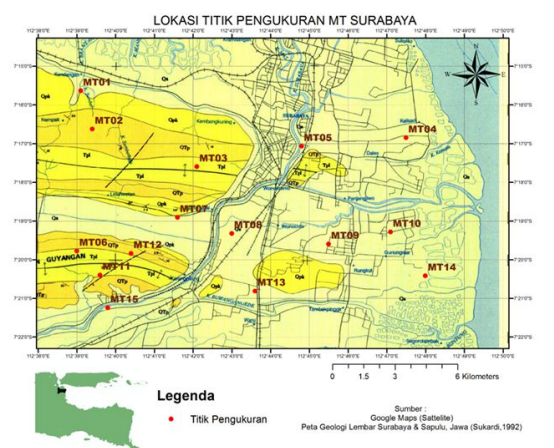

Fig. 6. Design for Measurement of the Magnetotelluric Surabaya Method (Red Point).

Table 1. Location of Magnetoteluric Measurement Points in Surabaya.

\begin{tabular}{|c|c|c|c|}
\hline TitikPengukuran & Latitude & Longitude & Elevasi (m) \\
\hline MT10 & -7.32 & 112.79 & 19 \\
\hline MT09 & -7.33 & 112.76 & 24 \\
\hline MT07 & -7.32 & 112.69 & 22 \\
\hline MT03 & -7.29 & 112.70 & 44 \\
\hline MT12 & -7.33 & 112.67 & 33 \\
\hline MT11 & -7.34 & 112.66 & 35 \\
\hline MT01 & -7.26 & 112.65 & 25 \\
\hline MT13 & -7.35 & 112.73 & 37 \\
\hline MT05 & -7.28 & 112.75 & 23 \\
\hline MT06 & -7.33 & 112.65 & 35 \\
\hline MT02 & -7.28 & 112.66 & 45 \\
\hline MT15 & -7.35 & 112.66 & 23 \\
\hline MT08 & -7.32 & 112.72 & 22 \\
\hline MT14 & -7.34 & 112.80 & 23 \\
\hline MT04 & -7.28 & 112.79 & 19 \\
\hline
\end{tabular}

Determination of the $\mathrm{x}$ and $\mathrm{y}$ direction is adjusted to the dominant strike direction in the measurement area. The strike direction can be obtain from geological data. In general, to facilitate measurement, the direction of $\mathrm{x}$ corresponds to 0 degrees or north-south direction, while $\mathrm{y}$ is adjusted to 90 degrees or east-west direction. The data received will be rotated later in accordance with the 
existing strike degree. Magnetotelluric data obtained from acquisitions in the field can not be separated from noise disturbances so that data processing is needed (Simpson and Bahr, 2005). The results of data processing are graphs of apparent resistivity and phase in the frequency function. The resistivity model for depth is obtained from the results of inversion, which shows the structure in the form of folds, estimation of faults and multilayered structures of subsurface resistivity of the study area.

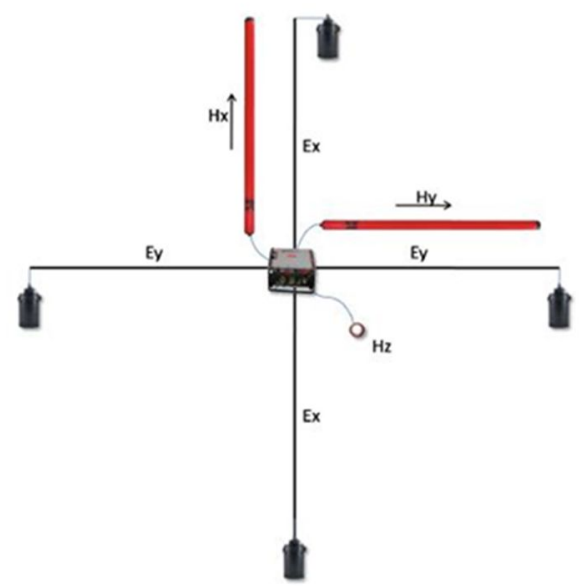

Fig. 7. Arrangement of Magnetotelluric Method Tools.

Table 2. Value of resistivity (Telford, 1990).

\begin{tabular}{|c|c|}
\hline Material & Resistivity $(\mathbf{\Omega m})$ \\
\hline Udara & $\sim$ \\
\hline Pirit & $0,1-100$ \\
\hline Kwarsa & $500-800000$ \\
\hline Kalsit & $1 \times 10^{12} \times 1 \times 10^{13}$ \\
\hline GaramBatu & $30-1 \times 10^{13}$ \\
\hline Granit & $200-10000$ \\
\hline Andesit & $1,7 \times 10^{2}-45 \times 10^{4}$ \\
\hline Basal & $200-100000$ \\
\hline Gamping & $500-10000$ \\
\hline BatuPasir & $200-8000$ \\
\hline BatuTulis & $20-2000$ \\
\hline Pasir & $1-1000$ \\
\hline Lempung & $1-100$ \\
\hline Air Tanah & $0,5-300$ \\
\hline Air Asin & 0,2 \\
\hline Magnetit & $0,01-1000$ \\
\hline KerikilKering & $600-1000$ \\
\hline Aluvium & $10-800$ \\
\hline Kerikil & $100-600$ \\
\hline &
\end{tabular}

\subsection{Rock resistivity}

Rocks are composed of various minerals and have electrical properties. Some rocks are composed of only one type of mineral, a small part is formed by a combination of minerals, and organic materials and volcanic materials. The electrical properties of rocks are characteristic of rocks in delivering an electric current. Rock can be considered as an electric medium like in an electric conductive wire, so it has a type of resistance (resistivity). Rock resistivity is an obstacle of rocks to electricity. Rock resistivity is influenced by porosity, water content and minerals. (Table 2)

Provide sufficient details to allow the work to be reproduced by an independent researcher. Methods that are already published should be summarized, and indicated by a reference. If quoting directly from a previously published method, use quotation marks and also cite the source. Any modifications to existing methods should also be described.

\section{Results}

Most earthquakes in the world occur in subduction zones where the power is up to $8 \mathrm{Mw}$, which can destroy an area up to thousands of kilometers from the epicenter (Lay, 2015). In addition, the recorded history of earthquakes on the island of Java shows the occurrence of a series of earthquakes on land that is not related to megathrust. Harris and Major (2016) reported at least 8 major earthquakes in Central and Northwest Java. Geomorphology and tectonic studies also support the existence of active faults on Java (Simandjuntak and Barber, 1996; Dardji et al., 1994; Malod et al., 1995). At present, there is little knowledge of Javanese tectonics. Recent studies focusing on offshore Java mapping structures using seismic reflection data understand the dynamics along the western Java boundary (Kopp et al., 2006, 2009; Schlüter et al., 2002). However, detailed crustal structures are unknown. Simandjuntak and Barber (1996) mapped the main fault system on Java, including the fault of Baribis and Kendeng along the East-West region and showed some parts of the area that were still active. Furthermore, the Magnetoteluric and geomagnetic studies show the existence of a Central Java fault, namely the strike-slip fault trending northeast-southeast, indicating a transition zone from Central Java to the eastern part of the Kendeng Basin (Hoffmann-Rothe et al., 2001). Recently, Koulali et al. (2016) identified an extension or active extension of Flores back-arc thrust to the west along $300 \mathrm{~km}$ on land to East Java along Pateng Kendeng. However, this structure is still not understood and this system can be continuous until the Baribis Fault (about $25 \mathrm{~km}$ south of Jakarta). The results of this study indicate the threat of a new large earthquake for East Java and the threat of a tsunami to Bali, Lombok, Nusa Tenggara, and other beaches along the Flores Sea. Simandjuntak and Barber (1996) map the main thrust systems, including the WestEast Baribis and Kendeng faults. Information about faults near the surface is the basis of studies of deformation studies in deeper areas.

From the results of the interpretation of magnetoteluric data that has been carried out, information is given about the alleged existence of an active fault crossing the city of Surabaya, consisting of 3 fault segments. Two of the three segments were previously known from the results of the 2017 PusGen study, namely the Kendeg Fault Waru Segment and Surabaya Segment. The third fracture identified has a 
larger and deeper geometry and its position between the two known faults (Fig 8 and 9).

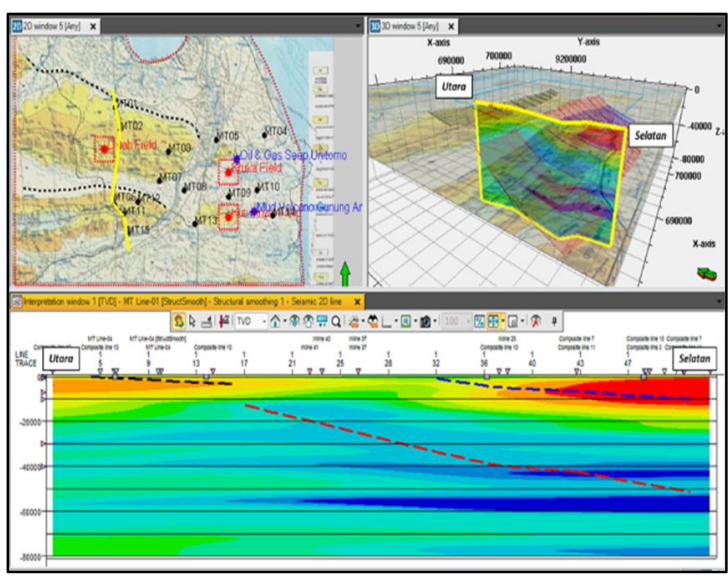

Fig. 8. Identification of active fault structure from 2D magnetotelluric data.

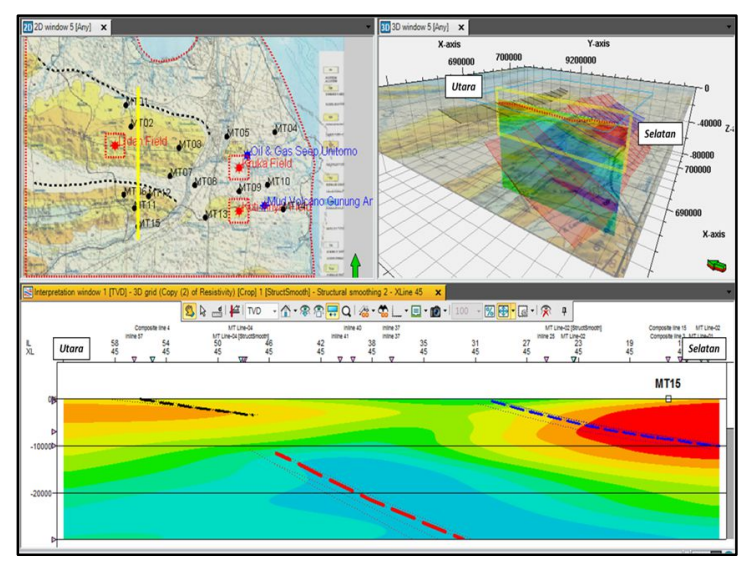

Fig. 9. Identify active faults from the 3 Dimensional resistivity magnetotelluric model data.

\section{Discussion}

The potential of earthquake sources is very decisive in determining earthquake hazards, therefore geometric information and location of potential sources are very important. Based on previous research, it has been stated that there are two active faults in the study area that cross the city of Surabaya, namely the Surabaya segment of Kendeng fault and Waru segment, and are stated to have the potential to produce earthquakes with magnitude 6.5. Based on the geometry that has been known, the Surabaya fault has a length of approximately $24 \mathrm{~km}$ and a waru fault $65 \mathrm{~km}$ with a depth ranging from 3 to 20 $\mathrm{km}$.

By identifying other faults that have a larger geometry, is it possible that this fault has the potential to produce earthquakes that have magnitudes greater than 6.5. From magnetotelluric data, there is a vertical geometry that can be well identified, while for long dimensions, additional data is needed, especially those extending westward from the city of Surabaya, so that the potential source of the earthquake that may be generated from this fault field can be calculated (Fig 10).

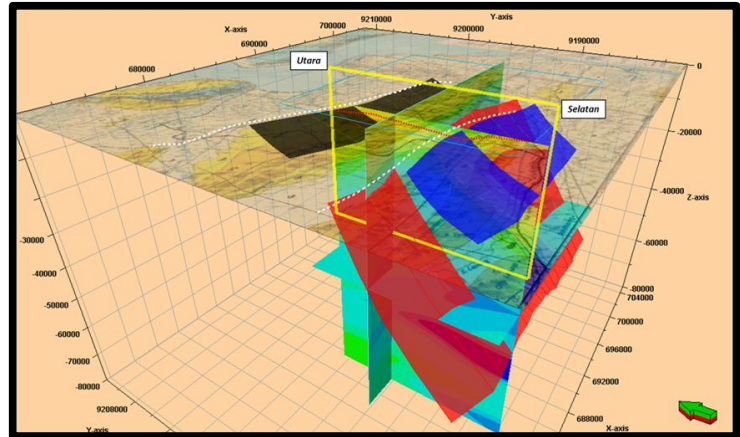

Fig. 10. Fault model of magnetotelluric data.

\section{Conclusions}

Referring to the results of the 2017 PusGen study that there was a potential source of the earthquake in the form of an active fault crossing the city of Surabaya, this study was conducted to confirm this information. From the results of this study, several conclusions can be drawn:

1. Magnetoteluric method is able to provide information on the subsurface conditions of the Surabaya and surrounding areas well.

2. The patterns and dimensions of the active geological structures that develop in the Surabaya region and beyond can be identified based on the resistivity values from the measurement results of the Magnetoteluric Method.

3. Three types of faults that crossed the city of Surabaya were identified, namely the two previously known faults, the Kendeng Waru Segment and the Surabaya Segment Fault, and the third fault, which had a larger dimension and a deeper position.

4. The third fault has the potential as a source of a large earthquake based on its larger dimension than the two known faults.

5. From the 3D resistivity model, the inversion of magnetotelluric data can be identified well with the Kendeng fault that crosses the city of Surabaya, both the Waru segment and the Surabaya segment at a depth of less than $8 \mathrm{~km}$.

\section{Refferences}

1. Dardji, N., Villemin, T., Rampnoux, J., J. Southeast Asian Earth Sci. 9 3-11. (1994)

2. Hoffmann-Rothe, A., Ritter, O., Haak, V., Phys. Earth Planet. Inter. 124 131-151.(2001)

3. http://litbang.pu.go.id/beranda/post/pulaujawa-siaga-gempa-7-5-sr

4. Koulali, A., Susilo, S., McClusky, S., Meilano, I., Cummins, P., Tregoning, P., Lister, G., Efendi, J., Syafi'i, M.A., Geophys. Res. Lett. 43 1943-1949. 2016GL067941.(2016)

5. Lay, T., Earth Planet. Sci. Lett. 409 133-146. (2015)

6. Simandjuntak, T.O. dan Barber, A.J., Geol. Soc. (Lond.) Spec. Publ. 106 185-201.(1996) 
7. Simpson, R. dan Bahr, K., Practical Magnetotellurics. Cambridge University Press (2005)

8. Supandjono, J., Hasan, K., Panggabean, H., Satria, D. dan Sukardi, Geologi Lembar Surabaya dan Sapulu, Pusat Penelitian dan Pengembangan Geologi, Bandung. (1992)

9. Telford W. R., Applied Geophysics Second Edition. New York: Cambridge University Press (1990)
10. Van Bemmelen, R.W., The Geology of Indonesia, The Hague: Government Printing Office. (1949)

11. Widodo, A., Warnana, D. D., Lestari, W., Syaifuddin, F., EAGE-HAGI 1st Asia Pacific Meeting on Near Surface Geoscience and Engineering (2018) 